\title{
A Challenge to Undergraduate Educators: The Wingspread Conference on International Education
}

\author{
Michael G. Schechter, Michigan State University
}

The cold war appears to be over; its most vivid symbol-the Berlin Wall-is being torn down, its pieces falling prey to capitalism. The Vietnam syndrome of avoiding military conflicts at almost all costs has dissipated, if not disappeared. Franco-German enmity has been replaced by the promises of 1992 . Japan has caught up with the Soviet Union in terms of gross national product. The United States has turned into the world's greatest debtor nation, and Japan has replaced it as the country providing the most foreign aid to "third world" countries. Most political scientists would agree that we are living through the most dramatic systemic change since the end of World War II.

But much of this drama and the import of these events is lost on American undergraduates. Lacking a sense of what came before, they cannot be expected to recognize the significance of the events of the past twelve months. In countless national, international, and regional studies, our undergraduates have been found to be ignorant of basic facts of history, geography, and current affairs. See, e.g., Strength Through Wisdom, 1979; Commission on International Education, American Council of Education, n.d.; Lurie, 1981; Southern Growth Policies Board, n.d.; Advisory Council on International Education of The Southern Governors' Association, 1986; National Governors' Association, 1989. It is clear from these reports that American undergraduates need a better sense of their position in history and in the world community.

To develop concrete measures to meet this challenge, 20 political scientists joined 27 academic colleagues from across the country (see Appendix 1 ) in a conference sponsored by The Atlantic Council of the United States at the Johnson Foundation's Wingspread Conference Center in Racine, Wisconsin, on September
15-17, 1989. The American Political Science Association joined a number of other professional associations in identifying members to join the Atlantic Council's Academic Associates in developing a strategy to address the continued neglect of international education. This challenge was forcefully presented to them by a Joint Working Group of

\section{Recent surveys of U.S. colleges and universities evidenced that more than $75 \%$ of them are engaged in reforming under- graduate curricula.}

the Atlantic Council and the Citizens Network for Foreign Affairs:
The education most Americans receive neither fits them nor predisposes them to deal with the growing demands of international intercourse. We are, as a nation, ill-informed about foreign policy issues, unfamiliar with foreign cultures, unskilled in foreign lan- guages, and except in moments of crisis-unimpressed with the impor- tance to us of our own international agencies and programs. In the words of French writer Jean-Jacques Servan- Shreiber, Americans "ignore that there is a world of human beings outside the borders of the U.S. . . "' or of the Mexican writer Carlos Fuentes, "What the U.S. does best is to understand itself. What it does worst is to under- stand others." (U.S. Leadership, 1987).

The premise of the Wingspread Conference was drawn from Thomas Jefferson, that one of the important purposes of higher education is "to inform [the] discretion of future citizens" by educating U.S. college graduates-to prepare them to be effective citizens and employees and to meet their responsibilities as leaders and opinion makers of their country in an increasingly interconnected and complex world.

The Wingspread conferees' specific charge was to develop a model General Education course to assist institutions of higher learning in improving college teaching about the history, structure, issues, and geopolitical characteristics of post-World War II international issues. This particular strategy for attacking American parochialism, which Rose Lee Hayden has ironically but aptly called "an inexhaustible and infinitely renewable resource," was selected for a number of reasons:

1. At most institutions of higher education, General Education provides the learning shared in common by all students, whether they study for degrees in the liberal arts and sciences or in the professions. Such an approach, where implemented, would also prepare high school teachers of social studies to be better qualified for their duties and responsibilities.

2. Recent surveys of U.S. colleges and universities evidenced that more than $75 \%$ of them are engaged in reforming undergraduate curricula. Most are giving special attention to General Education ("ACE Survey," 1988).

\section{Most colleges and university General Education programs require courses in which instruc- tion in the history and conduct of international relations can be incorporated.}

Given the great diversity of financial and human resources, admissions criteria, missions, and demographic characteristics of undergraduates at the institutions that the conferees represented, it was evident that a variety of course approaches should be considered. These took basically 
two forms, reflecting the way most institutions provide General Education knowledge to their undergraduates.

In some instances, the courses proposed were interdisciplinary, to be either team-taught or taught by specially recruited, trained, and rewarded faculty. An interdisciplinary approach, as explored by a group chaired by a George Washington University political scientist, Mickey East, would expose students to a wide variety of disciplines, providing them with a sense of the interconnectedness of issues and the inherent interdisciplinary nature of solutions to emerging global problems. Such courses could take several forms: instructors might choose any issue and look at it from various disciplinary perspectives; they might choose a set of issues or an issue uniquely amenable to interdisciplinary investigation and exploration.

In other instances, the courses developed were discipline specific, taught by faculty trained within a single discipline alone and augmented by guest lecturers from other disciplinary perspectives. A disciplinary approach would provide students with a perspective or analytical framework through which to approach complex global problems and to assess alternative solutions. A course of this nature was tentatively sketched out by a group largely composed of political scientists and chaired by Linda Brady of Georgia Institute of Technology. Brady's group identified the central concepts that should be included in any such course: security, broadly defined to include economic, cultural, ecological, and social dimensions as well as war and peace issues; interdependence and other cross-national interactions, often grouped under the rubric of international political economy; and the relationship between the processes by which political decisions are made and their consequences for the natural resources held in common by the earth's population, i.e., the oceans, the atmosphere, and other global resources that do not respect the political divisions among countries. As an analytical framework they were attracted to the notion of "change and continuity," the lietmotif of fellow conferees Charles Kegley and Eugene Wittkopf's major American foreign policy textbook (Kegley and Wittkopf, 1987).

A second variant of this approach evolved from a group, chaired by Yale historian Gaddis Smith. Their suggested syllabus (which is reproduced as Appendix 1 in Post World War II International Relations As a Component of General Education in American Colleges and Universities, 1989) includes 27 lecture topics: 1945 and 1990, A Geographic and Geopolitical Overview; The Impact of the Second World War; the Collapse of Colonial Regimes; Myths and Realities of the Superpowers; The Reconstruction and Division of the Cold War; Nationalism and Communism in Asia; The Korean War and the French Departure from Indochina; Religion and Nationalism in Africa; Economic Growth, Poverty, and Urbanization in Latin America; Hemispheric Relations and Institutions; America and Vietnam; Oil and the Political Problem of the World; Dreams and Nightmares of a Nuclear Age; Democracy and Authority in Latin America; The Twin Revolutions: Communications and Computers; North-South: Developed, Developing and Newly Industrializing Nations-The Global Dialogue; World Health, Population, Economic Growth, and the Environment; Japan and the World

Economy; The Economic and Political Integration of Europe; The Fragmentation of Conflict; Transformation of World Power: Challenges to the Nation-State; The Crisis of Communism: The USSR and Eastern Europe; The Crisis of Communism: The People's Republic of China; The United States in a Transformed World; Reflections: 1945 and 1990 Reconsidered. Obviously any course of this nature was recognized to be radically incomplete. Indeed, conferees believed that the side benefits of such a wide-ranging course offered early in students' academic careers would be to assist them in selecting disciplinary majors, to provide them with orientations for approaching questions in issue courses, and to whet their appetites to enroll in additional, in-depth courses.

While the Wingspread conferees were generally comfortable that they had made significant strides towards developing apt General Education courses, they were not content to leave without articulating a number of additional strategies. They favored the development of comparative and international modules for inclusion in existing courses including the development of introductory disciplinary courses with a contemporary international emphasis (e.g., political science, economics, geography, history, sociology). This would, among other things, avoid the possibility that a single term or semester General Education course might be the one, short introduction to international issues. Political scientists with a desire to pursue this path should read Sven Groennings' and David Wiley's newly edited work Group Portrait: Internationalizing the Disciplines (1989). There, in a section also developed with the support of the American Political Science Association, essays authored by Suzanne Berger, Leon Epstein, Gerhard Loewenberg, Susanne and Lloyd Rudolph, and Ole Holsti offer perspectives on increasing the comparative content of political science.

The conferees also believed that focusing on the curriculum and on courses was not enough. They identified a number of other strategies to prepare students for the 21st century. Two of the most prominent were: study, work experiences, and research abroad; and meaningful interactions with international students and scholars on campus. They also recommended a number of less traditional strategies, such as altering the reading and writing assignments in freshman composition courses to include works of non-U.S. authors and including readings on international issues and non-U.S.authored materials in the recommended reading lists that many colleges send to entering students.

While the Wingspread conferees believed that they had met the charge identified for them, they left knowing that the ultimate success of the conference depended on convincing their colleagues to implement the suggested curricular and co-curricular strategies. 


\section{Appendix 1}

M. Mark Amen,

University of South Florida.

Stephen Bailey, Knox College.

John A. Baker, The Atlantic Council

William Berentsen, University of Connecticut

Thomas Bierstaker,

University of Southern California

Linda P. Brady,

Georgia Institute of Technology

Rondo E. Cameron,

Emory University

Mark Curtis, The Atlantic Council

Vincent Davis, University of

Kentucky

Maurice East, George Washington University

H. Richard Friman, Marquette University

Samuel Gammon, American Historical Association

Nicholas Gerogiannis,

Auburn University

David Gordon, University of North Carolina, Charlotte

Susan Graseck, Brown University

Sven Groennings, University of Georgia

Grant Hammond, Air War University

Jay Harris, University of Nebraska

Nadine I. Hata, El Camino College

Barbara Hetrick, Hood College

Antoinette Iadarola, Colby-Sawyer College

James Johnson, Rutgers University

Charles W. Kegley, University of South Carolina

Gerald Kleinfeld, Arizona State University

Robert Kvavik, University of Minnesota

Clara Lovett, George Mason University

Jeffrey D. Kukenbill, Miami-Dade
Community College

Sheilah Mann, The American

Political Science Association

Geraldine Mannion, The Carnegie

Corporation

Myron A. Marty, Drake University

Kathleen McGinnis, Trinity College

Jack Perry, Davidson College

Robert Rotberg, Tufts University

Jack Sbrega, Community College of Rhode Island

Michael G. Schechter, Michigan State University

Randolph Siverson, University of California, Davis

Max Skidmore, University of Missouri

Cortland Smith, University of the Pacific

Gaddis Smith, Yale University

Susan Socolow, Emory University

Allen Splete, Council of Independent Colleges

Allen Springer, Bowdoin College

Kala Stroup, American Association of State Colleges and Universities

Russell G. Warren, James Madison University

Gerhard Weinberg, University of North Carolina

Craig Wilson, Eastern Montana College

Eugene R. Wittkopf, Louisiana State University

\section{References}

"ACE Survey Examines Trends in International Studies." 1988. Higher Education \& National Affairs. 17 October.

Advisory Council on International Education, The Southern Governors' Association. 1986. Cornerstone of Competition. Washington: Southern Governors' Association.

Atlantic Council of the United States. 1989.
Post World War II International Relations As a Component of General Education in American Colleges and Universities.

Washington: The Atlantic Council of the United States.

Commission on International Education, American Council on Education. N.d. What We Don't Know Can Hurt Us: The Shortfall in International Competence.

Washington: American Council on Education.

Groennings, Sven and David S. Wiley. 1989. Group Portrait: Internationalizing the Disciplines. New York: The American Forum.

Kegley, Charles W. Jr., and Eugene R. Wittkopf. 1987. American Foreign Policy: Pattern and Process. Third Edition. New York: St. Martin's Press.

Lurie, Joseph. 1981. American . . Globally Blind, Deaf and Dumb: A Shocking Report of Our Incompetence, Through Ignorance, In Dealing with Other Countries. Garden City: Adelphi University.

National Governors' Association. 1989. America in Transition: The International Frontier. Report of the Task Force on International Education. Washington: National Governors' Association.

Southern Growth Policies Board. N.d. Internationalizing Education in Southern Universities. Southern International Perspectives, No. 15. Research Triangle Park: Southern Growth Policies Board.

Strength Through Wisdom: A Critique of U.S. Capability. 1979. A Report to the President from the President's Commission on Foreign Language and International Studies. Washington: U.S. Government Printing Office.

U.S. International Leadership for the 21st Century: Building a National Foreign Affairs Constituency. 1987. Washington: n.p..

\section{About the Author}

Michael G. Schechter is professor of international relations, James Madison College of Michigan State University, and assistant dean of international studies and programs at Michigan State. He served as rapporteur at the Wingspread Conference. 